\title{
Developed to Basic Mathematic Instructional Activity of Flipped Mastery Approach Classroom via Self- directed Learning for Supporting Analytical Thinking Skills and Achievement of 11 Great Students
}

\author{
Rungnapa Arayathamsophon ${ }^{1}$, Pornchai Jedaman ${ }^{2}$, and Benjapuk Jongmuanwai ${ }^{3}$
}

\begin{abstract}
Purpose of this research to developed to basic mathematic instructional activity of flipped mastery approach classroom via self- directed learning for supporting analytical thinking skills and achievement of 11 great students. Participants were 183 students. The collection to synthesis a documentary study, by the basic mathematic instructional activity, by evaluation questionnaire, and the test to the data. The results were summaries of basic mathematic instructional activity of flipped mastery approach classroom via self- directed learning are divided of a preparing for instruction there are six components, content import to four elements, flipped mastery approach classroom via self- directed learning process it is divided to two processes of learning outside classroom with augmented reality to three components, with classroom instruction to two components, evaluation to three components. The efficiency by using basic mathematic instructional activity of flipped mastery approach classroom via self- directed learning have to process efficiency score of 90.56 and output efficiency scores of 93.56. Analytical thinking skills of students and the achievement were to higher than pretest at .05 level of significance. The students to responsible for their own learning efficiency.
\end{abstract}

Keywords:- Basic Mathematic Instructional Activity, Flipped Mastery Approach Classroom, Self- Directed Learning, Analytical Thinking Skills and Achievement.

\section{INTRODUCTION}

A direction of education management in Thailand 4.0 era make to the sectors of education in become to more aware of future changes, from emphasis on innovation and technology to assist in learning management. Jedaman. P., and Others [1] a mentioned to development and empowerment of human resources was another issued of learning management affective in the development of students to become a complete human being, have intelligence, the skills and developed of learning system that is responsive to the changes in the $21^{\text {st }}$ century. Learning management to focuses on having learning skills and having a mindful of learning all the time. [2]
A new learning model was designed and changing teacher roles that points out the importance that teachers need to adapt and change, include the development of student-centered for learning management capabilities. A learning in the $21^{\text {st }}$ century focuses on cognitive skills and critical thinking, besides of learning academic content, students need to know how to continue learning, know how to use what you have learned effectively and create learning and thinking skills of critical thinking and problem solving skills, communication skills, creative skills and innovative production, including collaboration skills. [3] How to modify ideas to create educational innovation under a concept into the $21^{\text {st }}$ century learning there are the concepts of developing students to have qualifications ready for life and cope with the changes that will occur in the future. Also, the flipped classroom becomes an innovative and one perspective example from the actual experience it takes, this is how to use the classroom to create value for students by applying knowledge in various situations to create learning of mastery learning. Bergmann J. and Sams A [4] the flipped mastery classroom was learning management that changed the use of time of lectures in classroom content be doing various activities to create knowledge and apply knowledge on the students to have more time to learn truthfully and take action, for the study part, the lesson content will be spent at home through the technology provided by the teachers. The teacher role has completely changed, that is not the importer of knowledge, but the teacher is like a coaching or an idea sparkler by asking questions to strengthen students' of analytical thinking skills and as a learning facilitator for students in a creating new knowledge to effectively. And self- directed learning is an essential part of learner qualifications that require web or internet-based instruction, students will have a high responsibility for directing and self-control, study by yourself, the teacher will be a facilitator and make resources available, must interact between students and teachers and between the students themselves. [5] The developed to basic mathematic instructional activity of flipped mastery approach classroom via self- directed learning for supporting analytical thinking skills and achievement of 11 great students in this study have three main the objectives to, a) developed to basic mathematic instructional activity of flipped mastery approach classroom via self- directed learning for supporting analytical thinking skills and achievement, b) study to the efficiency by using basic mathematic instructional activity of flipped mastery approach classroom via self- directed 
learning in contents learning an according to specified criteria of $80 / 80$, c) assessment to the analytical thinking skills in learning management on basic mathematic contents, and d) compare the achievement between beforeafter instructional.

\section{REVIEW LITERATURE}

\section{$>$ Instructional Activity of Flipped Mastery Approach Classroom via Self-Directed Learning:-}

Flipped classroom was the instructional of childcenter education and relying on technology to fully develop classroom teaching for enable the students to create knowledge in their brains. And the mastery learning of the main principle is that students learn according to their objectives, which to flipped mastery classroom were the presentation of dimensions of effecting the students in various aspects for change the educational paradigm by teaching students to take responsibility for their own learning, the students will appreciate and will transform into owners of their own learning. Filling the classroom with a variety of activities. [6] The focus is on what students have learned or not yet in a classroom like this that the students come to the classroom with their learning goals, teachers an organizing classroom objects and learning facilities include guidelines to the students have to plan their own learning, and coordinate their use during learning, changing and increasing the teachers role to mentor and expert, teachers get to know students better, where teachers' duties are not just helping students get knowledge or content but must to encourage an inspiration for support students. Which is an important dimension that will enhance the development of students' learning and increase the interaction between students as well, from the learning activities that teachers provide experiences so that students can help and support each other. [7] Are the paradigm shift of students who have studied according to teachers or complete tasks as scheduled into learning for oneself of affect the interaction and value between each other. Self- directed learning is an essential part of learner qualifications that require web or internet-based instruction, students will have a high responsibility for directing and self-control, study by yourself, the teacher will be a facilitator and make resources available, must interact between students and teachers and between the students themselves. A self-lead learning is a process in which learners to take the initiative to analyze and decide as they want to learn. After that as set a learning goal, identifying research methods that will lead to success including able to review and review their academic achievement and success. [8] The learning by allowing students to lead themselves can help train them to be self-reliant, and self-development that helps to generate internal motivation. Which can stimulate the need to learn and helps learning with purpose as well as being used for more benefits. Flipped mastery approach classroom via self- directed learning into the students will be self- directed learning of ideas before moving in other topics, the students can work independently or in a team, peer group for study and monitor student progress and encourage students to study to increase their potential, by providing the best opportunities for difference in the classroom for giving the opportunity to learn as the contents beyond the objective, which the students will be able to perform different actions at each level to achieve purpose and use a variety of content on the site that can be spent studying at any time according to availability for meet the needs of students through online media and using a website of instructional as communicate between teachers and students. [9] Also, the basic mathematic instructional activity of flipped mastery approach classroom via self- directed learning into preparing for instruction, content import, flipped mastery approach classroom via self- directed learning process, and evaluation.

\section{$>$ Analytical Thinking Skills and Learning Achievement: -}

Learning management to develop as analytical thinking skills are the development of thinking skills that emphasize thought processes for problem solving, critical thinking, interpretive thinking, analytical and synthetic thinking, retrospective thinking, discriminative thinking, coherent thinking, and ranking thinking. By the results of the teaching and learning process that will cause students to change behavior and can be measured into cognitive, psychological, and cognitive skills. [10] From to the assessment of analytical thinking skills of the basic mathematic instructional activity of flipped mastery approach classroom via self- directed learning to assessment of the elements as opening up learning opportunities, having their own perception of being an effective learner, initiative and freedom of learning, responsibility for one's own learning, a love of learning, creativity, optimism, the ability to apply study skills and problem solving skills. The learning achievement is the ability of students in various fields, which caused students to gain experience from the teaching and learning process of teachers. From to the contents instructional of basic mathematic as the exponents, the probability, the sequence, and the series.

\section{THE METHODOLOGY}

The methodology of the research was action research classroom into developed to basic mathematic instructional activity of flipped mastery approach classroom via selfdirected learning for supporting analytical thinking skills and achievement of 11 great students.

\section{> Data Method:-}

The data method into the instruments were to, 1) basic mathematic instructional activity of flipped mastery approach classroom via self- directed learning of a preparing for instruction, content import, flipped mastery approach classroom via self- directed learning process, and evaluation, 2) the efficiency by using basic mathematic instructional activity of flipped mastery approach classroom via self- directed learning of 11 great students in contents learning an according to specified criteria of $80 / 80$ into the contents of the exponents, the probability, the sequence, and the series, 3) the analytical thinking skills of opening up learning opportunities, having their own perception of being an effective learner, initiative and 
freedom of learning, responsibility for one's own learning, a love of learning, creativity, optimism, the ability to apply study skills and problem solving skills, 4) compare the achievement between before- after instructional into the method.

\section{Population and samples:-}

The population in this study were the students in Chumpharsuksa School, Thailand who were studying in 11 great of the 2019 academic year. The samples used in this study were 183 students in learning to the contents instructional of basic mathematic. And the experts as learning management of 13 persons. The participants they all were by purposive sampling.

\section{Data Tools:-}

The data tools were to the interview questionnaire of structure for developed to basic mathematic instructional activity of flipped mastery approach classroom via selfdirected learning, an instructional plan as the contents of basic mathematic, and the evaluation questionnaire of analytical thinking skills as the arrangement of questions in different directions by organizing a list of questions into positive and negative messages together on the answer type is an estimation scale of 5 levels, the achievement test of multiple choice type, choose to answer 4 options, there are to have item of objective congruence and confidence of $0.86,0.89$, respectively.

\section{$>$ Data Collection:-}

The data collection in this study were to; Step1: to analyzed the documentary study and related research to get the basic results of development conceptual framework including to develop a conceptual framework. Step2: to interview with the experts, and to analyzed and synthesized, and set a conceptual framework into developed to basic mathematic instructional activity of flipped mastery approach classroom via self- directed learning. Step 3: before conducting instructional have been tested to analytical thinking skills by the evaluation questionnaire and testing basic mathematic knowledge with the test to recorded as scores before. Step 4: bring the basic mathematic instructional activity of flipped mastery approach classroom via self- directed learning together with instructional plan for learning management with the students as the contents of the exponents, the probability, the sequence, and the series for studying the efficiency an according to specified criteria of $80 / 80$. Step 5: after all instructional as the contents to assessment to the analytical thinking skills by the evaluation questionnaire and testing basic mathematic knowledge with the test to recorded as after scores, and to compare the scores to find the differences between before-after scores to the data.

\section{Data Analysis:-}

The data analysis for the qualitative data was analyzed by using three main stages, i.e., data reduction, data organization, data interpretation to conclusion. The quantitative data was analyzed by descriptive statistical analysis including percentage, mean, standard deviation, and t-test.

\section{SUMMARIES}

The developed to basic mathematic instructional activity of flipped mastery approach classroom via selfdirected learning for supporting analytical thinking skills and achievement of 11 great students to summaries were followed:

A. Basic mathematic instructional activity of flipped mastery approach classroom via self- directed learning:-

Into $4^{\text {th }}$ steps to shown at figure 1.
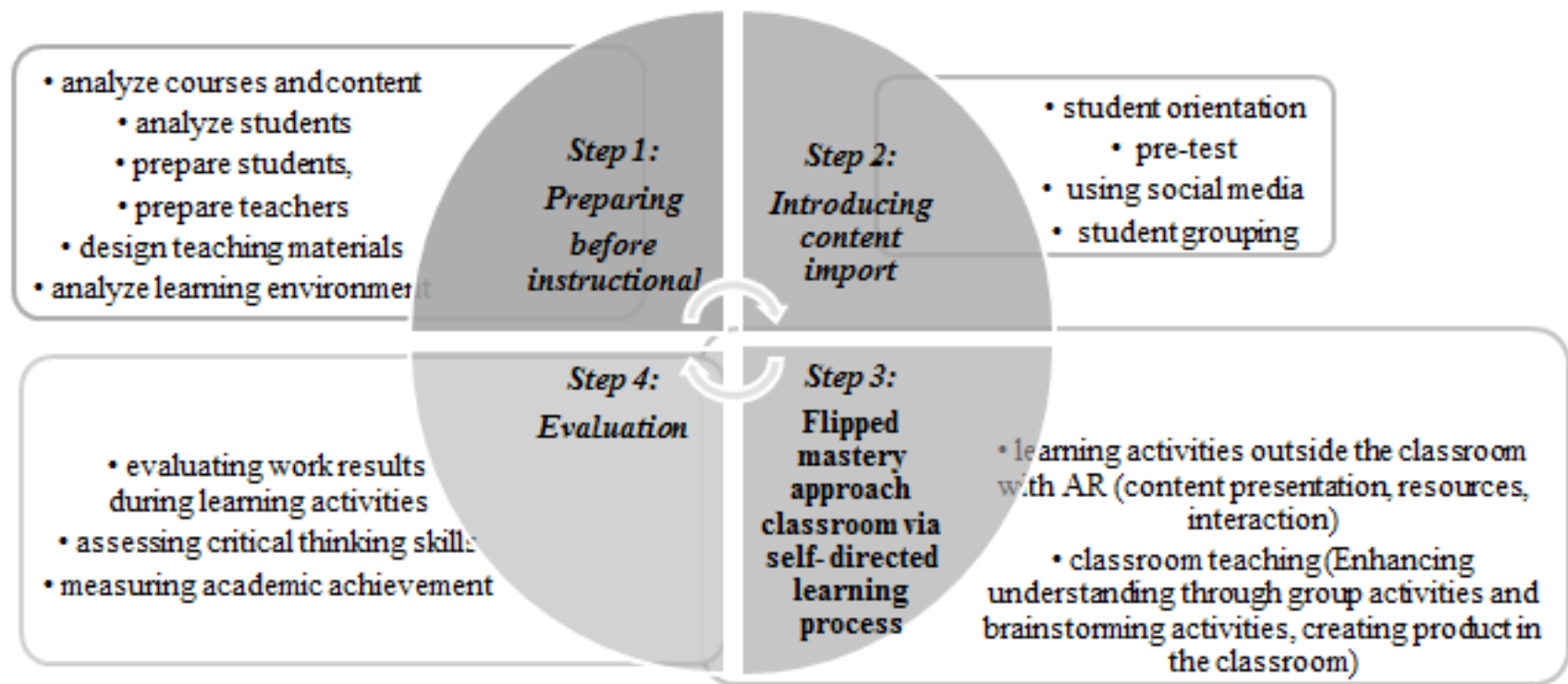

Fig 1:- The $4^{\text {th }}$ steps of Basic mathematic instructional activity of flipped mastery approach classroom via self- directed learning 
Basic mathematic instructional activity of flipped mastery approach classroom via self- directed learning as $4^{\text {th }}$ steps of preparing for instruction there are six components, content import to four elements, flipped mastery approach classroom via self- directed learning process it is divided to two processes of learning outside classroom with augmented reality to three components, with classroom instruction to two components, evaluation to three components were followed;

Step 1: Preparing before instructional: there are six components of, 1) analyze courses and content for set the learning objectives and prepare a learning management plan, 2) analyze students of the knowledge and competencies into information and communication technology, which is the basis for learning as flipped mastery approach classroom via self- directed learning, 3) prepare students to have knowledge and be able to use information and communication technology as learning, 4) prepare teachers of modify teaching methods, with a student-centered emphasis, 5) design teaching materials of augmented reality technology, and 6) analyze learning environment of factors that support teaching and learning, such as equipment, hardware, software, and networking, the internet.

> Step 2: Introducing content import: on the content import as four elements of; 1) student orientation to explain to the students at the details of the subjects content, objectives of learning management plans, action activities, and evaluation criteria, 2) pre-test to measure the foundation of knowledge and learning skills of students in the subject matters, 3) using social media into in communication to exchange knowledge between each other as a group and collaborative learning process, 4) student grouping by requiring grouping to promote teamwork and help each other learn to achieve the group's goals.

$>$ Step 3: Flipped mastery approach classroom via selfdirected learning process: it is divided into two processes of learning outside the classroom with augmented reality have three components, with classroom instruction has two components there are to;
- learning outside the classroom to, (1) content presentation with teachers creating content and presenting content through augmented reality media, (2) information resources as to identify various sources of information necessary for learning and give students the freedom to research additional resources on their own, by using the connection theory as learning is born from a variety of opinions, learning is the process of linking between sources of information that learning can take place from the things around, being connected is necessary for continuing learning, perception is a link between principles and ideas, knowledge that is up to date is the purpose of learning activities, and decision making is a learning process, (3) interaction, where students can interact with students together or with teachers to exchange and learn together, include ask for more information via social media channels using a common learning principle by collaborative learning of contributes to the development of students' thinking process, and get feedback about their own work from fellow members, helps to get to know fellow members better, resulting in good relationship with each other.

- classroom instruction to, (1) enhancing understanding through group activities And brainstorming activities (e.g., discussion, content / problem review, from instructors and students discussing content and questions in the class), (2) create works in the subject matter of practical learning Using the principles of learning throughout learning by doing.

> Step 4: Evaluation: Into three components of, 1) evaluating work results during learning activities, assessing critical thinking skills, measuring academic achievement

B. Efficiency of basic mathematic instructional activity of flipped mastery approach classroom via self- directed learning:-

The efficiency of basic mathematic instructional activity of flipped mastery approach classroom via selfdirected learning in contents learning of the exponents, the probability, the sequence, and the series an according to specified criteria of $80 / 80$ to shown at table1.

\begin{tabular}{|c|c|c|c|}
\hline \multirow{2}{*}{$\begin{array}{c}\text { Basic mathematic instructional in } \\
\text { contents learning }\end{array}$} & \multicolumn{2}{|c|}{ Scoring efficiency } & \multirow[b]{2}{*}{ Efficiency criteria } \\
\hline & Process efficiency & $\begin{array}{c}\text { Out } \\
\text { efficiency }\end{array}$ & \\
\hline Exponents & 89.75 & 91.50 & $89.75 / 91.50$ \\
\hline Probability & 90.50 & 92.25 & $90.50 / 92.25$ \\
\hline Sequence & 90.75 & 94.50 & $90.75 / 94.50$ \\
\hline Series & 91.25 & 96.00 & $91.25 / 96.00$ \\
\hline Totals & 90.56 & 93.56 & $90.56 / 93.56$ \\
\hline
\end{tabular}

Table 1:- Scoring efficiency of basic mathematic instructional in contents learning

The efficiency of basic mathematic instructional activity of flipped mastery approach classroom via self- directed learning in contents learning of the exponents, the probability, the sequence, and the series have to process efficiency score of 90.56 and output efficiency scores of 93.56., That to highest than specified criteria of 80/80. Efficiency criteria of 90.56/ 93.56.

\section{The analytical thinking skills of the students:-}

Analytical thinking skills of the students into opening up learning opportunities, having their own perception of being an effective learner, initiative and freedom of learning, responsibility for one's own learning, a love of learning, creativity, optimism, the ability to apply study skills and problem solving skills to shown at table 2-3. 
ISSN No:-2456-2165

\begin{tabular}{|c|c|c|c|c|c|c|}
\hline \multirow[t]{2}{*}{ Analytical thinking skills } & \multicolumn{3}{|c|}{ Before learning } & \multicolumn{3}{|c|}{ After learning } \\
\hline & $\overline{\bar{X}}$ & S.D. & Levels & $\overline{\mathrm{X}}$ & S.D. & Levels \\
\hline 1. Opening up learning opportunities & 2.95 & 1.10 & Middle & 3.73 & 0.94 & High \\
\hline $\begin{array}{l}\text { 2. Having their own perception of being an } \\
\text { effective learner } \\
\text { 3. Initiative and freedom of learning }\end{array}$ & 3.40 & 0.89 & Middle & 4.34 & 0.66 & High \\
\hline 4. Responsibility for one's own learning & 3.25 & 0.93 & Middle & 3.93 & 0.87 & High \\
\hline $\begin{array}{l}\text { 6. Creativity } \\
\text { 7. Optimism }\end{array}$ & 3.39 & 0.85 & Middle & 4.37 & 0.75 & High \\
\hline 8. Ability to apply study skills and problem & 3.42 & 0.98 & Middle & 4.10 & 0.76 & High \\
\hline solving skills & 3.40 & 0.98 & Middle & 4.21 & 0.77 & High \\
\hline & 3.42 & 0.98 & Middle & 4.33 & 0.74 & High \\
\hline & 3.45 & 0.73 & Middle & 4.17 & 0.83 & High \\
\hline Totals & 3.32 & 0.93 & Middle & 4.15 & 0.79 & High \\
\hline
\end{tabular}

Table 2:- Comparing mean and standard deviation of analytical thinking skills, before and after learning

\begin{tabular}{|c|c|c|c|c|c|}
\hline Analytical thinking skills & $\mathrm{N}$ & $\overline{\mathrm{X}}$ & S.D. & $\mathrm{t}$ & Sig. \\
\hline Before learning & 183 & 3.32 & 0.93 & & \\
After learning & 183 & 4.15 & 0.79 & $7.86^{*}$ & 0.00 \\
\hline
\end{tabular}

$* \mathrm{p}<0.05$

Table 3:- Comparing analytical thinking skills before and after learning, by t-test

Analytical thinking skills of students into opening up learning opportunities, having their own perception of being an effective learner, initiative and freedom of learning, responsibility for one's own learning, a love of learning, creativity, optimism, the ability to apply study skills and problem solving skills of after learning to higher than before learning at .05 level of significance.

\section{Basic mathematic knowledge achievement of the students:-}

Basic mathematic knowledge achievement of the students in contents learning of the exponents, the probability, the sequence, and the series into compare the achievement between before- after instructional to shown as table 4 .

\begin{tabular}{|c|c|c|c|c|}
\hline Basic mathematic knowledge achievement & N & Scoring & t & Sig. \\
\hline Before & 183 & 24.79 & $36.29 *$ & 0.00 \\
After & 183 & 33.42 & \\
\hline
\end{tabular}

$* \mathrm{p}<0.05$

Table 4:- Comparing Basic mathematic knowledge achievement before and after learning, by t-test

Basic mathematic knowledge achievement of the students in contents learning of the exponents, the probability, the sequence, and the series of posttest to higher than pretest at .05 level of significance.

\section{DISCUSSIONS}

Basic mathematic instructional activity of flipped mastery approach classroom via self- directed learning as $4^{\text {th }}$ steps of preparing for instruction there are six components, content import to four elements, flipped mastery approach classroom via self- directed learning process it is divided to two processes of learning outside classroom with augmented reality to three components, with classroom instruction to two components, evaluation to three components. The efficiency of basic mathematic instructional activity of flipped mastery approach classroom via self- directed learning in contents learning of the exponents, the probability, the sequence, and the series have to process efficiency score of 90.56 and output efficiency scores of 93.56., That to highest than specified criteria of 80/80. Efficiency criteria of 90.56/ 93.56.
Analytical thinking skills of students into opening up learning opportunities, having their own perception of being an effective learner, initiative and freedom of learning, responsibility for one's own learning, a love of learning, creativity, optimism, the ability to apply study skills and problem solving skills of after learning to higher than before learning at .05 level of significance. And basic mathematic knowledge achievement of the students in contents learning of the exponents, the probability, the sequence, and the series of posttest to higher than pretest at .05 level of significance, this is because a providing students with critical thinking skills thus enabling learners to develop their abilities and knowledge under a setting objectives, students study lessons from home, students spend time synthesizing in classroom, evaluation of students, learning create new knowledge, from self-guided learning are to the teacher to organizes learning according a coach and the students are the practitioners, motivating teacher to guide the learning management and students are eager to learn, teacher is the facilitator and the students are involved in learning. Jack F, Eichler, \& Junelyn Peeples. [6] Flipped classroom modules for large enrolment general 
chemistry courses: a low barrier approach to increase active learning and improve student grades. The teacher a giving advice and students to self- directed learning for creating new knowledge by using the website as the primary medium for teaching and learning that can be easily accessed, that teachers give out website address (URL) and QR Code for students to access, an orientation to understand the teaching and learning process steps, recommend the use of the website used as a medium, introducing menus for use in each lesson unit, introducing the usage of chat room and the steps to study the lesson content, answering questions after studying the lesson content and submitting work, links to external learning resources, include recommend a website usage page so that students can find out how to use the website by themselves that the website has a different display suitable for each device. Mary Beth Gilboy, Scott Heinerichs, \& Gina Pazzaglia. [7] Enhancing student engagement using the flipped classroom there is a user manual that is convenient to use the website and is beautiful to attract learners to study the content by themselves, the illustrations and videos are consistent with the content presented to enable students to develop analytical thinking from answering questions. Ajjima Bamrungna [8] by teachers including a facilitator in performing services, providing convenience and arrangements in the learning process, giving advice by providing some information to students in order to keep their thoughts from being scattered and unable to find the point, as a manager by planning, organizing, spending time managing information, creating pieces, creating agreements with the students, an evaluation of the results, which will examine the understanding, knowledge and ability to opinions and contributions of the students. The students acknowledge of learning and understand what the teacher explains in the teaching and learning, is a leader in learning topics and team groups in research studies, the operator of the preparation of knowledge from the study to create as group work to presented in the class, and responsible, division of duties in building knowledge.

\section{IMPLEMENTATIONS}

Basic mathematic instructional activity of flipped mastery approach classroom via self- directed learning and have the achievement indicators with clear main goals to consistent with the learning content, this will increase the students' knowledge, skills, attitudes and abilities. By through the process as $4^{\text {th }}$ steps of preparing for instruction there are six components, content import to four elements, flipped mastery approach classroom via self- directed learning process it is divided to two processes of learning outside classroom with augmented reality to three components, with classroom instruction to two components, evaluation to three components of effective implementation of learning management to analytical thinking skills and achievement of the students. Teachers should strengthen the motivation, and governance of procedures in teaching and learning that encourage the students to develop a researching for answers. And preparation of students and places, including equipment for conducting teaching and learning activities such as laboratory preparation, computer operation, internet signal to be in a ready state for provide effective teaching and learning management.

\section{REFERENCES}

[1]. Jedaman. P., Buraphan. K., and others. 2017. Analysis of Sustainable Leadership for Science Learning Management in the $21^{\text {st }}$ Century under Education THAILAND 4.0 Framework. International Conference for Science Educators and Teachers (ISET). AIP Conf. Proc. 1923, 030062-10; doi.org/10.1063/1.5019553.

[2]. Office of the Education Council, Ministry of Education. 2017. Policy and strategy development of education Quality. Bangkok, Thailand: Ministry of Education. The office.

[3]. Boriruk Nahaipol. 2015. Instructional for Digital Generation. The 6th International Conference on Human Resource and Organization Management and Development, National Institute of Development Administration (NIDA). Bankkok., Thailand.

[4]. Bergmann. J. and Sams. A. 2012. Flipped your classroom: Reach every student in every class every day. Eugene, OR: International Society for Technology in Education.

[5]. Supaporn Sudbanit and Others. 2013. Comparison Student responsibility, attitudes and achievement of students who have organized the Flipped Classroom conceptual learning activities and the regular learning activities. Journal of Faculty of Education: Mahasarakham University.

[6]. Jack F, Eichler, \& Junelyn Peeples. 2016. Flipped classroom modules for large enrolment general chemistry courses: a low barrier approach to increase active learning and improve student grades. The journal for teachers, researchers and other practitioners in chemistry education.

[7]. Mary Beth Gilboy, Scott Heinerichs, \& Gina Pazzaglia. 2015. Enhancing Student Engagement Using the Flipped Classroom. Journal of Nutrition Education and Behavior January-February, 47(1), 109-114.

[8]. Ajjima Bamrungna. 2014. Development of web-based teaching through self-directed learning for students Grade 6. Rajamangala University of Technology Thanyaburi, Thailand.

[9]. Walvoord, B. E., \& Anderson, V. J. 2011. Effective grading: A tool for learning and assessment in college: John Wiley \& Sons.

[10]. Zamzami, Zainuddin, Mohammad, \& Attaran. 2015. Malaysian students' perceptions of flipped classroom: a case study. 